\title{
A mulher infratora na visão do ministério público, do judiciário e no sistema penitenciário*
}

\author{
The female offender under the view of the Department of \\ Justice, Judiciary and inserted into the penitenciary sistem
}

\author{
José Ricardo Meirelles
}

Meirelles JR. A mulher infratora na visão do ministério público, do judiciário e no sistema penitenciário [tese]. Saúde, Ética \& Justiça. 2005;10(1/2):58-9.

\begin{abstract}
RESUMO: Considerando que as leis penais devem ser aplicadas indistintamente e sem preconceitos e tendo em conta as várias teorias criminológicas que tentam justificar o comportamento da mulher infratora e dos agentes que com elas lidam, estudos foram centrados na análise de casos envolvendo homens e mulheres - relacionados ao tráfico internacional de drogas e fraudes contra a Previdência Social - em seções judiciárias federais de notável relevância, de modo a verificar se de fato Procuradores da República e Juizes Federais dão tratamento diferenciado à mulher infratora. Supletivamente analisou-se a situação da mulher infratora no sistema penitenciário. A partir da análise das amostras, observou-se que Procuradores da República e agentes do sistema penitenciário dão tratamento diferenciado à mulher infratora sob suas duas vertentes - proteção e punição - de onde depreende-se que a dualidade santa-prostituta ainda se encontra presente no comportamento daqueles. Partiu-se, então, para a busca de novos parâmetros, de modo a nortear o comportamento daqueles profissionais, a partir da compreensão do crime como uma expressão da liberdade permitida do indivíduo, ou seja, como manifestação de sua individualidade, concretizada em atos, limitada por fatores internos e externos que vinculam o seu nível de expressão, bem como pelos direitos de personalidade. Somente assim, com a quebra de mitos e especialmente respeitando os indivíduos do sexo feminino como livres para expressar sua individualidade, sua personalidade, dentro de suas próprias opções éticas, é que se poderá tentar alcançar a tão almejada Justiça.
\end{abstract}

DESCRITORES: Mulheres. Crime/legislação \& jurisprudência. Prisões. Direito penal. Medicina legal.

\footnotetext{
* Tese de doutorado apresentada à Faculdade de Medicina da Universidade de São Paulo. Orientador: Cláudio Cohen
} 
Meirelles JR. The female offender under the view of the Department of Justice, Judiciary and inserted into the penitenciary system [tese]. Saúde, Ética \& Justiça. 2005;10(1/2):58-9.

\begin{abstract}
S: Considering that criminal law must be applyed identicaly and without any trace of prejudice and also considering the variety of criminologic theories that try to justify the female offender's behaviour and also the behaviour of the agents that handle with them, we targeted our studies to cases related to international drugs trafficking and social security fraud involving male and female gender in Federal District Court,in order to understand if the Federal Prosecutors and Federal Judges treat men and women differently.At the same time the female offender was analysed inside of the penitenciary sistem. While analysing some samples, could be seen that the Federal Prosecutors and penitenciary sistem treat the female offender differently from the male offender. This can be devided into two different paths - protection and punishment - inserted into the maddona-whore theory. Consequently new standards should lead the behaviour of Federal Prosecutors and people who deal with the penitenciary sistem, considering the crime as a human being free will influenced by internal and external factors and also by each person's personality. That's the only way to break the pre established patterns and accept the female gender free to express their personality and will and ethic options, and so this way for long reach Justice.
\end{abstract}

KEY WORDS: Women. Crime/legislation \& jurisprudence. Prisons. Criminal law. Forensic medicine. 